Hardwick RH, Barham CP, Ozua P, Newcomb PV, Savage P, Powell R, Rahamin J, Alderson D (1997) Immunohistochemical detection of p53 and c-erbB-2 in oesophageal carcinoma; no correlation with prognosis. Eur J Surg Oncol 23: $30-35$

Mimura K, Kono K, Hanawa M, Kanzaki M, Nakao A, Ooi A, Fujii H (2005a) Trastuzumab-mediated antibody-dependent cellular cytotoxicity against esophageal squamous cell carcinoma. Clin Cancer Res 11: 4898-4904

Mimura K, Kono K, Hanawa M, Mitsui F, Sugai H, Miyagawa N, Ooi A, Fujii $\mathrm{H}(2005 \mathrm{~b})$ Frequencies of HER-2/neu expression and gene amplification in patients with oesophageal squamous cell carcinoma. $\mathrm{Br} J$ Cancer 92: $1253-1260$

Miyazono F, Metzger R, Warnecke-Eberz U, Baldus SE, Brabender J, Bollschweiler E, Doerfler W, Mueller RP, Dienes HP, Aikou T, Hoelscher AH, Schneider PM (2004) Quantitative c-erbB-2 but not c-erbB-1 mRNA expression is a promising marker to predict minor histopathologic response to neoadjuvant radiochemotherapy in oesophageal cancer. $\mathrm{Br} \mathrm{J}$ Cancer 91: $666-672$

Sato S, Kajiyama Y, Sugano M, Iwanuma Y, Sonoue H, Matsumoto T, Sasai K, Tsurumara M (2005) Monoclonal antibody to HER-2/neu receptor enhances radiosensitivity of esophageal cancer cell lines expressing HER2/neu oncoprotein. Int J Radiat Oncol Biol Phys 61: 203-211

Shiga K, Shiga C, Sasano H, Miyazaki S, Yamamoto T, Yamamoto M, Hayashi N, Nishihira T, Mori S (1993) Expression of c-erbB-2 in human esophageal carcinoma cells: overexpression correlated with gene amplification or with GATA-3 transcription factor expression. Anticancer Res 13: $1293-1301$

Sunpaweravong P, Sunpaweravong S, Puttawibul P, Mitarnun W, Zeng C, Baron AE, Franklin W, Said S, Varella-Garcia M (2005) Epidermal growth factor receptor and cyclin $\mathrm{Dl}$ are independently amplified and overexpressed in esophageal squamous cell carcinoma. J Cancer Res Clin Oncol 131: $111-119$

Tanaka S, Mori M, Akiyoshi T, Tanaka Y, Mafune K, Wands JR, Sugimachi K (1997) Coexpression of Grb7 with epidermal growth factor receptor or Her2/erbB2 in human advanced esophageal carcinoma. Cancer Res 57: 28-31

Wang LS, Chow KC, Chi KH, Liu CC, Li WY, Chiu JH, Huang MH (1999) Prognosis of esophageal squamous cell carcinoma: analysis of clinicopathological and biological factors. Am J Gastroenterol 94: 1933-1940

\title{
Reply: Her2 (ErbB2) receptors, a potential therapeutic target in squamous cell carcinoma of oesophagus?
}

\section{J-P Metges*,I, L Gibault ${ }^{2}$, V Conan-Charlet ${ }^{2}$, P Lozac'H $^{3}$, M Robaszkiewicz ${ }^{4}$, C Bessaguet ${ }^{5}$, N Lagarde $^{2}$ and A Volant ${ }^{2}$}

'Institute of Oncology, Morvan Hospital, 5 Avenue Foch, 29609 Brest Cedex, France; ${ }^{2}$ Department of Anatomical Pathology, La Cavale Blanche Hospital, Boulevard Tanguy Prigent, 29609 Brest Cedex, France; ${ }^{3}$ General Surgery, La Cavale Blanche Hospital, Boulevard Tanguy Prigent, 29609 Brest Cedex, France; ${ }^{4}$ Hepato-Gastroenterology, La Cavale Blanche Hospital, Boulevard Tanguy Prigent, 29609 Brest Cedex, France; ${ }^{5}$ Biostatistics and Cancer Register Unit, Hepato-Gastroenterology, La Cavale Blanche Hospital, Boulevard Tanguy Prigent, 29609 Brest Cedex, France

\section{British Journal of Cancer (2006) 94, 12 I4-1215. doi:I0.1038/sj.bjc.660308 I www.bjcancer.com} (c) 2006 Cancer Research UK

Sir,

At first, we would like to thank you for giving us the opportunity to reply to this letter. It may be worth reminding that our study was aimed at gaining insight, from only immunohistochemical data, into the potential impact of several targets such as EGFR, Her 2 , p53, VEGF and ckit in a large and homogenous series of patients (107) with oesophageal squamous cell carcinoma. Our experiments showed a potential impact of EGFR status, and HER2 was found to be overexpressed by only $2.8 \%$ of the tumours (Gibault et al, 2005).

Before replying to the letter by Khan, it sounds us worth (i) recalling that there is a consensus among the scientific community about the difficulty of comparing data relative to the assessment of angiogenesis by immunohistochemistry (Vermeulen et al, 2002) and (ii) indicating that our bibliography section did not refer to the two very interesting and recent papers by Mimura et al $(2005 a, b)$ only because our manuscript had been submitted and accepted before the publication of both articles.

The remarks by Khan and co-workers are focused on the low rate reported by our team and on the potential role of HER 2 in squamous cell carcinoma of the oesophagus. We totally agree

*Correspondence: Dr J-P Metges;

E-mail: jean-philippe.metges@chu-brest.fr with them about the fact that several analyses of HER2 carried out by immunohistochemistry or other methods (Shiga et al, 1993; Hardwick et al, 1997; Tanaka et al, 1997; Friess et al, 1999; Wang et al, 1999; Akatmatsu et al, 2003; Miyazono et al, 2004; Mimura et al, 2005a, b; Sato et al, 2005; Sunpaweravong et al, 2005) have all found rates of overexpression greater than $2.8 \%$. To our opinion, the differences observed between these different studies have several origins: the first of them, as clearly said by Khan and coworkers is the high heterogeneity in the methodologies used in the collection of studies cited by these authors. For example, Friess studied adenocarcinoma and squamous cell carcinoma and used an antibody and a semiquantitative procedure both different from ours (Friess et al, 1999). Among the available methods, the Dako Herceptest for immunohistochemical assay is considered as the most reliable one for the detection of a positive HER-2 status; this consideration drove us to use it and evaluate the staining as described by Penault-Llorca et al (2002). Concerning Mimura and co-workers, in addition to immunochemistry they performed a Her2 gene amplification with the aim to optimise their search for HER2 expression. However, by a careful reading of their paper in Clinical Cancer Research (Mimura et al, 2005a) one learns that, after the study of squamous cell lines, they analysed Her-2 expression in freshly isolated tumours (primary tumour and malignant pleural infusion from two patients; both samples were 
found to show no staining in Herceptest despite Her2 expression in flow cytometric analysis. In the second study (Mimura et al, 2005b) published in the British Journal of Cancer, they evaluated only HER2 in a homogenous series (66 cases) of squamous cell carcinoma of the oesophagus treated by surgery; one should note that, despite the lower number of cases under study, these investigations and ours can be compared. Among their cohort of patients, only three of them denoted $(3+)$ were identified by immunochemistry as being positive; six others, denoted $(2+)$, were considered as positive cases. When they compared the HER2 status between primary and metastatic lymph nodes, they clearly found a strong correlation, but only in the three HER2 $(3+)(4.5 \%$ of the cases). FISH analysis revealed a gene amplification in the three strongly positive cases, that is $(3+)$, in three out of the six samples denoted $(2+)$ and in one out of the 11 weak positive patients termed $(1+)$. To our knowledge, this study is the only report describing HER2 status in oesophageal neoplasms from results of the two FDA-approved tests. The finding that one patient with herceptest $1+$ was positive for gene amplification suggests an underestimation of the rate of HER2-positive cases by this test.

Ongoing experiments within our laboratory are focused on a FISH analysis of our cohort of 126 patients. It should allow us to get data comparable with those reported by Mimura about 66 cases.

As we also wonder about the impact of cultural habits, ethnic differences between populations of the different continents, it would be also worth carrying out an intercomparison of HER2 and
EGFR data in cohorts of patients from geographical areas where the incidence of squamous cell carcinoma is high (Japan, China, France or other countries) obtained by strictly using the same methodology to eventually highlight a difference of status in relation with the origin of patients and their food habits. Her-2 status is generally determined by FISH and immunohistochemistry. To our opinion, the serum HER2 is worth being analysed. Indeed, we reported at the ASCO GI 2006 symposium preliminary results about HER2, EGF, P53, VEGF and IL6 analysed by ELISA in the serum of patients treated by radiochemotherapy for oesophageal squamous cell carcinoma: pretherapeutic serum HER2 and serum EGF levels seemed to be strongly correlated $(P=0.017)$. Moreover, serum HER2 levels suggested an association with progression $(P=0.059)$ and metastatic status $(P=0.006)$; but only pretherapeutic serum EGF levels were associated with overall survival $(P=0.046)$ (Metges et al, 2006).

In conclusion, we think that HER2 is a potentially interesting target in oesophageal neoplasms. According to Mimura, Herceptest $3+$ patients are the best candidates for anti-Her2 immune targeting; this subgroup of patients represents a relatively low proportion of the total population of oesophageal squamous cell carcinoma (Mimura et al, 2005b). However, further investigations needed to confirm these data. Prospective and homogenous series of patients required to analyse the potential interest of HER2 status by immunochemistry, serum analysis and gene amplification in the clinical course of patients with oesophageal squamous cell carcinoma.

\section{REFERENCES}

Akatmatsu M, Matsumato T, Oka K, Yamasaki S, Sonoue H, Kajiyama Y, Tsurumaru M, Sakai K (2003) c-erb2 oncoprotein expression related to chemoradioresistance in esophageal squamous cell carcinoma. Int $J$ Radiat Oncol Biol Phys 57: 1323-1327

Friess H, Fukuda A, Tang WH, Eichenberger A, Furlan N, Zimmermann A, Korc M, Buchler MW (1999) concommitant analysis of the epidermal growth factor receptor family in esophageal cancer: overexpression of epidermal growth factor receptor mRNA but not of c-erbB-2 and c-erbB-3. World J Surg 23: 1010-1018

Gibault L, Metges JP, Conan-Charlet V, Lozac'H P, Robaszkiewicz M, Bessaguet C, Lagarde N, Volant A (2005) Diffuse EGFR staining is associated with reduced overall survival in locally advanced oesophageal squamous cell cancer. Br J Cancer 93(1): $107-115$

Hardwick RH, Barham CP, Ozua P, Newcomb PV, savage P, Powell R, Rahamin J, Alderson D (1997) Immunohistochemical detection of p53 and c-erbB-2 in oesophageal carcinoma: no correlation with prognosis. Eur J Surg Oncol 23: 30-35

Metges JP, Guenet D, Codet JP, Moineau M, Volant A, Bizais Y, Robaszkiewicz M (2006) Potential significance of serum Her2/neu, EGFR, VEGf, IL6, and p53 in patients with esophageal squamous cell cancer (ESCC) treated by radiochemotherapy. Am Soc Clin Oncol Gastrointestinal cancers symposium, third Annual Meeting, San Francisco (abstract no. 45)

Mimura K, Kono K, Hanawa M, Mitsui F, Sugai H, Miyagawa N, Ooi A, Fujii $\mathrm{H}(2005 \mathrm{~b})$ frequencies of Her-2/neu expression and gene amplification in patients with oesophageal squamous cell carcinoma. $\mathrm{Br} J$ Cancer 92: $1253-1260$

Mimura K, Kono K, hanawa M, Kanzaki M, Nakao A, Ooi A, Fujii H (2005a) Trastuzumab-mediated antibody-dependent cellular cytotoxicity against esophageal squamous cell carcinoma. Clin Cancer Res 11: 4898-4904

Miyazono F, Metzger R, Warnecke-Eberz U, Baldus SE, Bradender J, Bollschweiler E, Doerfler W, Mueller RP, Dienes HP, Aikou T, Hoelscher AH, Scheider PM (2004) Quantitative c-erbB-2 but not c-erbB-1 mRNA

expression is a promising marker to predict minor histopathologic response to neoadjuvant radiochemotherapy in oesophageal cancer. $\mathrm{Br} J$ Cancer 91: 666-672

Penault-Llorca F, Balaton B, Sabourin JC, Le Doussal V (2002) Immunochemistry evaluation of HER2 status in infiltrating breast cancer: technical protocol and interpretation guidelines. Ann Pathol 22(2): $150-157$, [French]

Sato S, Kajiyama Y, Sugano M, Iwanuma Y, Sonoue H, Matsumato T, Sasai K, Tsurumaru M (2005) Monoclonal antibody to HER-2/neu receptor enhances radiosensitivity of esophageal cancer cell lines expressing HER2/neu oncoprotein. Int J Radiat Oncol Biol Phys 61: 203-211

Shiga K, Shiga C, Sasano H, Miyazaki S, Yamamoto T, Yamamoto M, Hayashi N, Nishihira T, Mori S (1993) expression of c-erbB-2 in human esophageal carcinoma cells: overexpression correlated with gene amplification or with GATA-3 transcription factor expression. Anticancer Res 13: $1293-1301$

Sunpaweravong P, Sunpaweravong S, Puttawibul P, Mitarnun W, Zeng C, Baron AE, Franklin W, Said S, Varella-Garcia M (2005) Epidermal growth factor receptor and cyclinD1 are independently amplified and overexpressed in esophageal squamous cell carcinoma. J Cancer Res Clin Oncol 131: $111-119$

Tanaka S, Mori M, Akiyoshi T, Tanaka Y, Mafune KI, Wands JR, Sugimachi K (1997) Coexpressionof Grb7 with epidermal growth factor receptor or HER2/erbB2 in human advanced esophageal carcinoma. Cancer Res 57: $28-31$

Vermeulen PB, Gasparini G, Fox SB, Colpaert C, Marson LP, Gion M, Belien JA, de Waal RM, Van Marck E, Magnani E, Weidner N, Harris AL, Dirix LY (2002) Second international consensus on the methodology and criteria of evaluation of angiogenesis quantification in solid human tumours. Eur J Cancer 38: $1564-1579$

Wang LS, Chow KC, Chi KH, Liu CC, Li WY, Chiu JH, Huang MH (1999) Prognosis of esophageal squamous cell carcinoma: analysis of clinicopathological and biological factors. Am J Gastroenterol 94: 1933-1940 